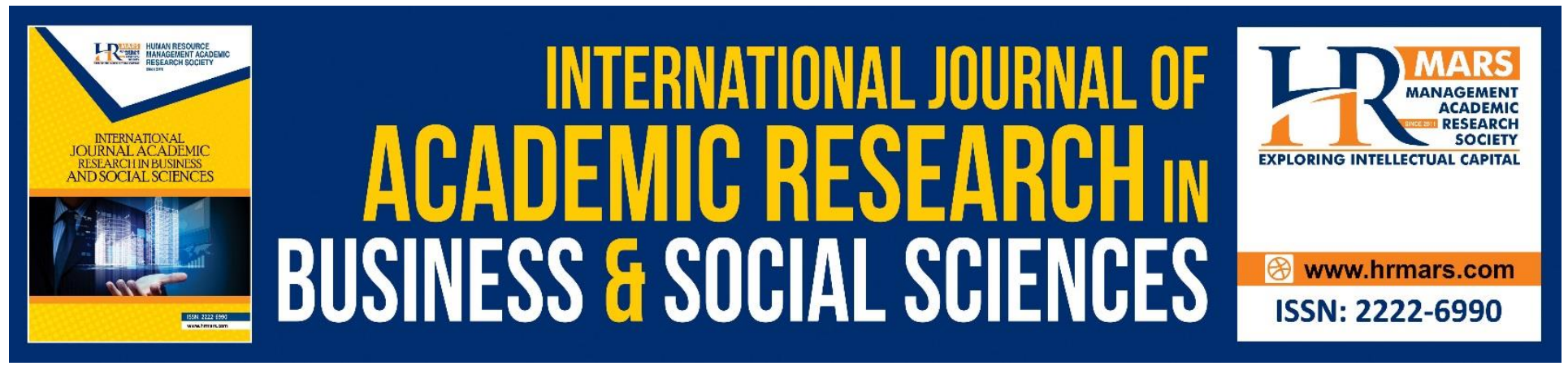

\title{
Community Development through Food Tourism: Exploring the Utilization of Local Food as Community Development at Rural Destination in Malaysia
}

Mohd Nazri Abdul Raji, Shahrim Ab. Karim, Mohd Mursyid Arshad, Farah Adibah Che Ishak

To Link this Article: http://dx.doi.org/10.6007/IJARBSS/v8-i10/4791

DOI: $10.6007 /$ IJARBSS/v8-i10/4791

Received: 11 Sept 2018, Revised: 15 Oct 2018, Accepted: 28 Oct 2018

Published Online: 05 Nov 2018

In-Text Citation: (Raji, Karim, Arshad, \& Ishak, 2018)

To Cite this Article: Raji, M. N. A., Karim, S. A., Arshad, M. M., \& Ishak, F. A. C. (2018). Community Development through Food Tourism: Exploring the Utilization of Local Food as Community Development at Rural Destination in Malaysia. International Journal of Academic Research in Business and Social Sciences, 8(10), 937-951.

Copyright: (c) 2018 The Author(s)

Published by Human Resource Management Academic Research Society (www.hrmars.com)

This article is published under the Creative Commons Attribution (CC BY 4.0) license. Anyone may reproduce, distribute, translate and create derivative works of this article (for both commercial and non-commercial purposes), subject to full attribution to the original publication and authors. The full terms of this license may be seen at: http://creativecommons.org/licences/by/4.0/legalcode

Vol. 8, No. 10, 2018, Pg. 937 - 951

http://hrmars.com/index.php/pages/detail/IJARBSS

JOURNAL HOMEPAGE

Full Terms \& Conditions of access and use can be found at http://hrmars.com/index.php/pages/detail/publication-ethics 


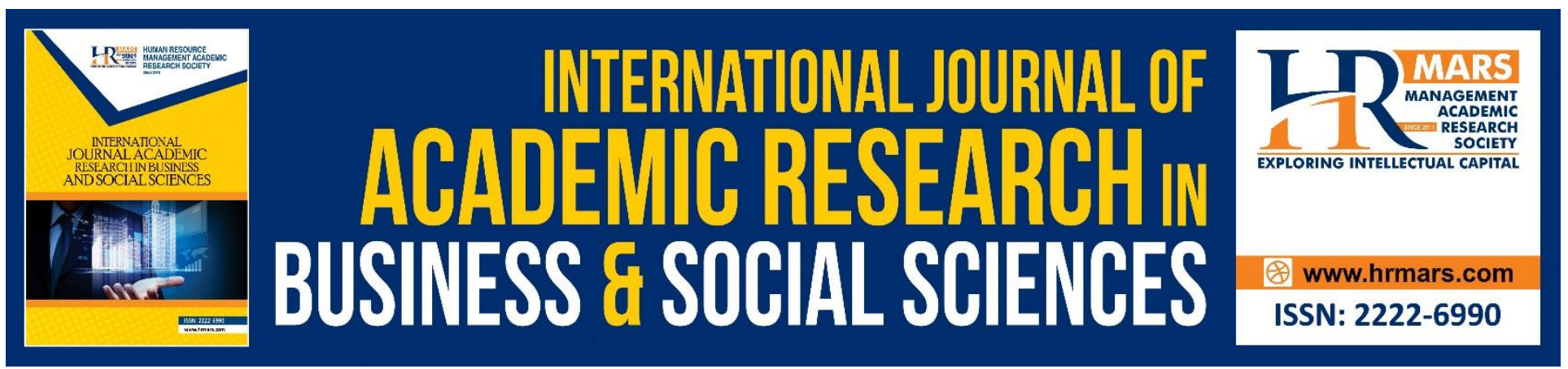

\title{
Community Development through Food Tourism: Exploring the Utilization of Local Food as Community Development at Rural Destination in Malaysia
}

\author{
Mohd Nazri Abdul Raji, Shahrim Ab. Karim, Mohd Mursyid Arshad, \\ Farah Adibah Che Ishak \\ Faculty of Educational Studies, University Putra Malaysia, 43400 UPM Serdang, Selangor Darul \\ Ehsan, Malaysia
}

\begin{abstract}
Many regions have recognized local foods as icons of their countries and act as one of important attributes of developing a destination. The availability of local foods provides travellers and local consumers with positive memorable experiences. Tourism destinations are competing to promote food tourism which is an emerging segment in the tourism industry. In this regard, rural destination is no exception. From the tourism perspective, rural destinations mainly focused on nature, historical sites, and practices of host community, landscape and cultural heritage as well as local food products. There are many benefits highlighting local food product as tourist attraction at rural destination. The importance of local foods at rural destinations to develop connection to the place, create diverse tourists' experience, and provide financial support to the local community well-being cannot be underestimated. Furthermore, in the context of rural area local food is considered as a symbol and practices of traditional culture heritage of the people. For instance, by participating in local food activities, tourists will have the opportunity to experience different local cultures and practices. Key stakeholders and relevant authorities of rural destinations must aware the advantage of local foods in promoting their destinations and the contribution to the local economy. By integrating local foods in rural destinations will help to strengthen destinations' sustainability competitiveness. However, without support from the local community, it will be impossible to promote the destinations. Technically, local community's participant is important to promote any tourism products particularly in rural destinations, as local communities can reflect the surroundings and how they can work together to benefit the community and visitors. Therefore, this conceptual paper explores the viability of the community of a rural destination using local foods as determinants towards rural tourism destination development.
\end{abstract}

Keywords: Local food, community development, rural destination, benefits of local food 
INTERNATIONAL JOURNAL OF ACADEMIC RESEARCH IN BUSINESS AND SOCIAL SCIENCES

Vol. 8, No. 10, Oct. 2018, E-ISSN: 2222-6990 @ 2018 HRMARS

\section{INTRODUCTION}

United Nations World Tourism Organization (UNTWO) 2016 reported that tourism industry has makes significant economic contribution in many countries; with some countries rely on tourism sector as a medium for growth and development. As revealed by World Travel and Tourism Council (2016), tourism industry has generated US\$ 7.2 trillion of world's Gross Domestic Product (GDP) in 2016 and employs more than 284 million people worldwide. By the year 2030 World Tourism Organization (WTO) forecasted that 1.8 billion tourists will be travelling around the world (UNTWO, 2016). The growing number of tourist arrival in destinations worldwide has turned it into a key driver of socio-economic progress through the creation of more jobs opportunities, export revenues and infrastructure development.

Government of Malaysia (2015) reported that tourism industry in Malaysia is the second major economy contributor after manufacturing. With the increase number of tourist arrivals from 25.72 million in 2015 to 26.76 million in 2016, tourism industry has now become most significant industry in Malaysia (Tourism Malaysia, 2017). It also forecasted that in the year 2020 tourist arrival to Malaysia will increase $13.6 \%$ annually to MYR 168 billion and is expected to provide 2.36 million jobs (Tourism Malaysia, 2016). From these figures, it shows that Malaysia tourism industry has pulled international recognition and has gained many attentions of tourists all around the world to choose Malaysia as their tourism destination.

To increase the number of tourist arrivals annually it required variety of marketing strategy. This is because tourism destinations are competing in generating income of the countries and regions (Ritchie \& Crouch, 2003). A competitive strategy is critically important for every tourist destinations in order to sustain in this industry. In this regards, a tourist destination in Malaysia is no exception. Moreover, as mentioned by Ritchie \& Crouch (2003), increasing competitiveness within tourist destination is difficult challenge that needs to be faced by the destination in the global marketplace. These challenges arise because destination strives to achieve multiple goals, which involves multiple tourist products, multiple stakeholders and multiple suppliers. The lacks of organization will give negative effect to the destination performance. Furthermore, today's tourists not only satisfied with the experience of accommodation and transportation as now they become more critical demanding (Renko, Renko, \& Polonijo, 2010). The same authors point out, the demands of current tourists to explore something new and different are increase due to the high in disposable income and they have more free time.

In recent years, rural tourist destination become popular attraction especially for travellers who are seeking for quiet places for relaxant and release their stress (Lin \& Yeh, 2013). Rural destination refers to activity that takes place at the remote area and tourists intentionally participate in this place to enjoy rural landscape scenery, seek physical and mental relaxation and become more closer to nature (Ballantyne, Packer, \& Hughes, 2009). In Malaysia, in attracting more international tourists to experience the natural beauty of the country and cultural diversity, several rural destinations have been recognized as World Heritage Site (WHT) by United Nations Educational, Scientific and Cultural Organization (UNESCO). Among these sites are Mulu National Park, Kinabalu National Park and Lenggong Valley. According to statistics most of international tourists visited the Kinabalu National Park and Mulu National Park. Lenggong Valley was found to be less visited by the international tourists (Ramli, 2017). In Lenggong Valley, tourists mainly come to visit the 
archaeological heritage sites such as the limestone caves, the tombs of dignitaries and numerous heritage building (Rasoolimanesh, Dahalan, \& Jaafar, 2016). Nevertheless, Lenggong Valley also offers various local food products that can be tapped into tourism product that have not been seriously explored. There are varieties of local plant species, freshwater fish, and popular production of high grade ikan pekasam; a staple of heritage Perak cuisine. As Hassan, Zakaria, Hamid, Rindam, \& Hamamah, (2013) argue Lenggong Valley is rich with archaeological resources and nonarchaeological resources such as lakes and rivers, flora and fauna, as well as cultural practices of host community including local foods that have seem to have the potential to be integrated together to improve the competiveness in the global tourism market. Local culture activities and practices in rural destination should not only be protected through conservation and preservation but also with the right strategies and plans, managed prudently, effectively and efficiently would able become attraction and marketable products to international or local tourists.

Currently, food has gain recognition by the local government, tourism producers of tourism services, destination management organisations, local authorities and researchers as an important part of the tourism product as well as to enhance the means for develop the destination competitiveness (Andersson, Mossberg, \& Therkelsen, 2017; Steinmetz, 2010). Previous studies have reported many countries and regions are now focusing the opportunities on the utilizing of local food products as important element in developing tourism marketing strategy (Ab Karim \& Chi, 2010; Bessière, 1998; du Rand, Heath, \& Alberts, 2003; Hashimoto \& Telfer, 2006). This is because there are increases of number tourists travel for a reason of seeking culinary experience (Long, 2004; Okumus, Okumus, \& McKercher, 2007). Moreover, according to Long (2004) food is one of the key elements that influence tourists in deciding a destination. Local produce such as traditional food prepared by local people can offer attractive experience to the tourist and encourage visit to the destination (Sims, 2009). As pointed by Long (2004) states that culinary tourism deal with 'foodway' which can be defines as cultural practices connected with food preparation and consumption such as how foods are prepared, served and consume by individuals. Thus, local food consumption is not only satisfied hunger for the tourists but can potentially be used as main attraction to a particular destination.

Additionally, in recent study by Lunchaprasith (2017) reveals local community who participated actively in promoting local food products at Amphawa Floating market, one of rural destination in Thailand received positive impact in term of economic, social and cultural. In tourism industry context, food service establishment is a major importance in generating jobs and income for many countries (du Rand et al., 2003) including Malaysia. Tourism stimulates the local economy through creating business opportunities and sales of locally-produced products brought by the tourists demand for food, which benefits the local community from revenue generated from food sales (Bessière, 2013). Furthermore, many studies argue that linking local food and tourism destination could benefits for both host and visitor (Boniface, 2003; Enteleca Research and Consultancy Ltd, 2000; Sims, 2009). This paper emphasizes on the benefits of local food to the local communities particularly at rural destinations. 
INTERNATIONAL JOURNAL OF ACADEMIC RESEARCH IN BUSINESS AND SOCIAL SCIENCES

Vol. 8, No. 10, Oct. 2018, E-ISSN: 2222-6990 @ 2018 HRMARS

\section{LITERATURE REVIEW}

\section{Food Tourism}

Food is considered as a reflection of culture of a region and its people. This is because as Wolf (2006) noting that food is manifestation of culture and helps countries and regions define what they are and what it means to be from there. Many scholars or researchers have highlighted the potential used of food to strengthen destination attraction. For example, study has found that local food is able to enhance a destination image by highlighting the food products in marketing their destination (Okumus et al., 2007). Furthermore, Getz, Andersson, Robinson, \& Vujicic (2013) argue there is increasing of numbers of tourists travel for a reason of food and gastronomy. This strategy is applicable for any destinations including rural areas. As Hall, C.M., Mitchell, \& Sharples (2003) assert the role of food and wine production within the context of tourism industry found that utilising food and wine as part of tourism experience potential to increase economic growth in rural areas. They argue in order to achieving this success, it is important to have strong support and collaboration between public and private sectors as well as the local community involvement.

Culinary tourism can be referred as a concept that tourist can experience other countries' culture through experiencing their foods (Long, 1998). On the other hand, many definitions of culinary tourism have been established by many scholars. Wolf (2006) defines culinary tourism as "travels in order to search for enjoy prepared food and beverage and unique memorable gastronomic experience". Culinary tourism also goes beyond the dining experience which it includes a variety of culinary activities, for example, a visit to a farmers market, attending food festivals, factory tours and discovery of a region's unique dishes (Deneault, 2002). This experience also has power to modify eating and drinking habit, as well as increase tourists' cultural experience of the place being visited (Kivela \& Crotts, 2006).

Generally, the labelled of 'food tourism', 'culinary tourism', or 'gastronomy tourism' have been used interchangeably in tourism context to explain the meaning of people travel to a particular destination for a reason of food and culinary related activities (Ab Karim \& Chi, 2010). In reality, most of the tourists will experience the food of other at some time, intentionally or unintentionally (Steinmetz, 2010). Food like other group of elements in tourism such as accommodation, transport, destination attraction and activities, is a basic element of the tourism product (A. Hjalager \& Corigliano, 2000). From previous studies, food is act as important element in many destinations and hold great potential to enhance tourist experience in many destinations (S. Kim \& Iwashita, 2016; Long, 2004; Samuel Folorunso Adeyinka-Ojo \& Khoo-Lattimore, 2013; Son \& Xu, 2013).

\section{Local Food}

Local food and drinks can be define as a product that is produced and grown in the local area, has a local identity of the culture (Enteleca Research and Consultancy Ltd, 2000). They also mentioned local speciality food had local identity and regional brand such as cheeses, meat and pies. As Nummedal \& Hall (2006) argue the definition of local food is not only about locally grown product, but should also include food that requires raw ingredients from outside the area and it processed locally. Local food is considered as a one of authentic product of particular community that is handed down from one generation to another. 
This can be seen in term of the pre-preparation, styles of cooking and the used of main ingredients that can highlight the difference between one place to another place (Raji, Ab Karim, Ishak, \& Arshad, 2017). As Siti Hajar Abd Aziz, Zuraini Zakaria, \& Ziyad Rafiqi Mohammad (2014) mention local food own by a particular community potentially conveys both the need and the culture vastly disparate regions, races, religions, availability of natural resources and eating habits. Previous research by López-Guzmán \& Sánchez-Cañizares (2012) emphasized that the role of local food is not only to satisfied a physical need for tourists but is an important element for understanding and learning about the regional identity and culture that give competitive advantages to the destination. Local food plays essentials role to market the cultural product of particular society through exchange experience between people (Siti Hajar Abd Aziz et al., 2014).

Basically, a local food product developed by a society from rural area gives more value to their local's cultural identity (Siti Hajar Abd Aziz et al., 2014). This includes their eating habits specifically evolved from the initial survival needs of particular community. The variety of ingredients used in traditional food originated from the available resources either harvested from the woods or the backyard in order to maintain the original taste of the food. In addition, the methods of cooking and the used of traditional equipment and tools show the different traditions at destination. The combination of ingredients and method of cooking used will increase the attractiveness and competitiveness of rural destination as outstanding destination. As Kivela \& Crotts (2006) mention food consumption is a unique form of tourist activity that requires all five senses which include vision, hearing, touch, smell and taste.

Local food products in tourist destinations may function as a point of attraction in its own right rather than being complementary element in tourism (Quan \& Wang, 2004). Current research has found local food at tourist destination helps to promote destination awareness, form destination identity, create tourist activity and contribute to tourist experience and satisfaction (Adeyinka-Ojo \& Khoo-Lattimore, 2016). In particular, consuming cuisine from another culture is likely to provide epistemic value, as most tourists consider local food consumption a novel experience and a means of expanding knowledge or cultural capital (Choe \& Kim, 2018). The success of utilizing local food as tourists' attraction has inspired other developing countries such as Thailand, Indonesia, Vietnam as well as Malaysia to highlight the range of distinctive foods in promoting their local food as part of their tourism products (Jalis, 2016).

\section{Community Development through Food and Tourism Relationship}

Tosun (2000) defines community participant in tourist destination development as "a form of action in which individuals take the opportunities and responsibilities of citizenship". This process requires the community to work with those who are able to provide assistance in planning, management and decision that will affect their condition and development. In the tourism development process, Timothy (1999) explains community participant can be seen from two perspectives: in the decision-making process and in the form of benefits brought by the development. Apart from the two perspectives views by Timothy, the involvement of community members in implementing tourism development project is essential towards a sustainable approach. As Cheong \& Miller (2000) mention by having positive community participant in destination planning development, local community will ensure that the best plans are taken care as well as gain job 
INTERNATIONAL JOURNAL OF ACADEMIC RESEARCH IN BUSINESS AND SOCIAL SCIENCES Vol. 8, No. 10, Oct. 2018, E-ISSN: 2222-6990 @ 2018 HRMARS

opportunities, enhance their understanding of the project, improve understanding of the benefits brought by tourist and provide them to control unwanted change and opportunity to use local resources. To encourage community participant in tourism development, relevant authorities such as tourism planner and community leaders can provide educational information programs such as training workshop and awareness programs in order to enhance their knowledge about tourism development in particular destination.

The relationship between food and tourism can also be applied in the recent research agenda which explores the concept of Integrated Rural Tourism (IRT) (Sims, 2009). The purpose of IRT as part of rural development strategy is to promote environmental, economic, social cultural sustainability in rural tourism destination and to empower local people involvement in tourism planning (Cawley \& Gillmor, 2008). IRT emphasizing a bottom-up approach that involves local community centrally and that is based on the publicly and privately owned natural and cultural resources, associated infrastructure, and interpretative facilities, as well as provision of accommodation, food, beverages, and goods (Cawley \& Gillmor, 2008). IRT is design to make optimal use of resources while at the same time protecting and enhancing them. Therefore, IRT is not just focused with the sustainability agenda in tourism industry but it is about creating growth rural communities and enhancing the local environment, economy and cultures which can be enjoyed by hosts as well as guest (Sims, 2009). Apparently, the incorporation of local food project can play an important role in the IRT agenda because they can embrace all these concerns simultaneously.

Previous study has shown that food is one of important element in contributing to sustainable tourism. For example, the increasing tourist consumption of local foods in rural destination can generate a multiple effect that will benefit to the local economy (Enteleca Research and Consultancy Ltd, 2000; Lunchaprasith, 2017). This is because tourist will spend on food; they need to eat whenever they travel (S. Kim \& Iwashita, 2016). Thus, destination must realize the importance of local food in boosting the tourism development as well as supporting the local economy (Haven-tang \& Jones, 2005). Second example, in term of environmental concern, producing more local food resource will help to minimized food miles which led researchers to argue that "buying local" is important in order to reduce its carbon footprint (Boniface, 2003; Pratt, 2013). According to Pratt (2013) food miles is the distance of the food being transported from farm or factory to the consumer. The same author asserts encouraging tourist "buying local" is help to preserve small-scale farmland in rural areas as the money spent remains among the local people. Tourists who participate in local food activity such as food event or cooking demonstration will obtain further understanding on the "story behind the food" by talking to the local food producer. Connecting consumers with the people and place that offer the food will enhance their stronger sense of place, their trust and pride of having been to the place, as well as building a positive relationship within the community. Thus, this results in benefit the both host community and tourists (Sims, 2009). Third example, tourism destination all over the world facing new challenge and rapid changes owing to recession, market globalization, social media in consumer engagement, intensified competition and the dynamic evolution of new technologies (UNTWO, 2016). Since competition is a global phenomenon, it essential requirement for the tourist destinations to start recognized the capabilities and strength in order to increase the numbers of visitors. To ensure the successful every destination must develop a range of local attraction that will differentiate it from other destinations. As Pearson \& Pearson, (2016) suggest promoting local food 
is one of the key elements that can help increase the popularity of a place and heighten destinations appeal. To support the notions (Bessière, (1998) and Y. G. Kim, Eves, \& Scarles, (2009) assert local foods considered iconic product which tourist will experience different from a normal routine.

Many countries have started to promote their array of local food products in order to improve destination competitive advantage at the same time to create what might be called as 'local taste' (Jalis, 2016) . This strategy is useful for rural destination since it can add value to the destination, such as a cultural base activity. Incorporating local food activities into tourism existing packages, can enhance destination awareness, diversify experience and encourage tourist to spend (Jalis, Che, \& Markwell, 2014). It also gives positive economy impact to the destination development and increasing community social wellbeing, particularly in rural areas. Table 1 below shows the lists of examples of past studies that are related to the benefits of local food in tourist destination.

Table 1: Summary of findings from reviewed articles

\begin{tabular}{|c|c|}
\hline Author(s) & idings \\
\hline $\begin{array}{l}\text { Lunchaprasith } \\
\text { (2017) }\end{array}$ & $\begin{array}{l}\text { Local food experiences which actively participate by the locals in Samutsongkram, } \\
\text { Thailand have positive economic, social and cultural impacts. It also reveals that the role } \\
\text { of local food experience helps to improve the wellbeing of local residents. }\end{array}$ \\
\hline $\begin{array}{l}\text { Adeyinka-Ojo } \\
\& \quad \text { Khoo- } \\
\text { Lattimore, } \\
(2016)\end{array}$ & $\begin{array}{l}\text { This study reveals that local food event play important role in developing rural tourism } \\
\text { Bario in Sarawak, Malaysia in term of market the destination. This strategy will be } \\
\text { successful with the cooperation between local community, tourism organization and } \\
\text { other tourism stakeholder. This food event also helps to generate income among the local } \\
\text { community. }\end{array}$ \\
\hline $\begin{array}{l}\text { S. Kim \& } \\
\text { Iwashita } \\
\text { (2016) }\end{array}$ & $\begin{array}{l}\text { Local food heritage (Japanase udon noodles) plays important role in developing the image } \\
\text { and identity of the region. It also acts as a tool of attraction for tourism development and } \\
\text { potentially can be develop as food tourism destination in Mizusawa, Japan. }\end{array}$ \\
\hline $\begin{array}{l}\text { Son \& Xu, } \\
(2013)\end{array}$ & $\begin{array}{l}\text { This study reports from the perspective of Western tourists, religious food at Buddhist } \\
\text { temple restaurants (Chinese and Japanese temple) means for novelty-seeking, sensory } \\
\text { pleasure and peak tourist experience. It also means for symbols of authenticity, prestige } \\
\text { and as a medium of cultural exploration. This study also found that Buddhist temple foods } \\
\text { portray cultural resource experience as attraction of the tourist. }\end{array}$ \\
\hline $\begin{array}{l}\text { Hjalager and } \\
\text { Johansen } \\
\text { (2013) }\end{array}$ & $\begin{array}{l}\text { presents economic sustainability } \\
\text { enhances the demand of service } \\
\text { s. }\end{array}$ \\
\hline $\begin{array}{l}\text { Everett and } \\
\text { Slocum, (2013) }\end{array}$ & $\begin{array}{l}\text { Promoting and selling local food products to tourists help to support the important } \\
\text { sustainability agendas that have been endorse by UK government bodies which are } \\
\text { traditional industries, job development, rural economies, encouraging social justice and } \\
\text { diversifying agriculture. The study also found that issues pertaining to the social capital } \\
\text { were particularly fundamental in helping realize agricultural and tourism objectives. }\end{array}$ \\
\hline Sims (2009) & $\begin{array}{l}\text { This study found that local food and drinks can play important role in the sustainable } \\
\text { tourism experience at two national park- Lake District and Exmoor in UK. Local food and } \\
\text { drink products appeals to visitor's desire for authenticity during their holiday. }\end{array}$ \\
\hline $\begin{array}{l}\text { Telfer and } \\
\text { Wall (1996) }\end{array}$ & $\begin{array}{l}\text { Established linkage between tourism industry and local food production will benefit both } \\
\text { sides in order to produce high quality local food products that delivered on time. At the } \\
\text { same time, the tourism industry will create a positive image to the local community. }\end{array}$ \\
\hline
\end{tabular}


INTERNATIONAL JOURNAL OF ACADEMIC RESEARCH IN BUSINESS AND SOCIAL SCIENCES

Vol. 8, No. 10, Oct. 2018, E-ISSN: 2222-6990 @ 2018 HRMARS

\section{Marketing Strategy for Rural Destination Development}

Tourism destination can improve the destination competitiveness by organizing effective marketing strategies which could be included innovation product, packaging, positioning and the promotion of the attraction (du Rand, G.E. \& Heath, 2006). To add, Wang, (2011) argues that a right and well-planned marketing strategy will help destination compete effectively. Marketing plan is refer to a formal document used by company in order to sustain and stay competitive in the global market (Goldsmith \& Tsiotsou, 2012). With a well-planned marketing strategy this will provide a clear lens of the concept and scope of the tourism destination, as well as assisting the marketing and management of the tourist itself (Wang, 2011). Since tourism destination is competing in global market, destinations need to identify their capabilities and strengths (Jenkins, Dredge, \& Taplin, 2011). Presenting a strong identity and positive image is ensuring that tourism destination successfully survives. Consequently, destinations must offer tourism product and service that correspond to the current market demand.

As the demand of local food increased, it has become an opportunity for destination marketers and service providers to explore the potential value of utilizing local food in promoting rural destination in order to provide uniqueness experience to the tourists. As Okumus et al., (2007) asserts every tourist destination should to differentiate itself in order to portray its visible and invisible product and services. In tourism contexts, presenting strong identity and positive destination image is important to attract tourist to a particular destination (Fields, 2002). Local food with a strong regional identity has emerged as a means for achieving this and meets the evolving needs of the contemporary tourist (Steinmetz, 2010). The way of creating image of a destination using local food product which could attract tourists is through media (Fields, 2002). This is a powerful tool to attract the attention of potential tourists, even for those who do not realized food as dominating motivator for their decision of vacation (Fields, 2002). As such, there is growing numbers of food television programme, culinary books and magazine as well as food blogs that portray the image of destination. Another ways of gathering the information relating to destination is through internet usage (Fields, 2002). As Ab Karim \& Chi, (2010) state the public information sources (television, books/magazine, newspaper and internet) are the most important tools in influencing tourist purchase decision to visit a destination. Thus, employing this strategy in rural destination makes people aware about the place and the destination's attendant attraction and adding to the competitive advantage of the destination

\section{DISCUSSION}

Generally, rural destination is the area that far from the cities with basic facilities and normally has some difficulty to reach by travellers. This make rural destination could be perceived by tourists to have certain qualities such as natural landscape, quietness and uniqueness (Brown \& Hall, 2000). As Jaafar, Kayat, Tangit, \& Yacob (2013) mention that each of rural destinations has its own unique attractions strength and advantages that are beneficial to the host community. Apart from rich with natural resource attractions, local culture activities and practices in rural destination play a vital role in rural destination development (Rahmani, Hajari, Karimian, \& Hajilo, 2013). This is because cultural activities and practises possess by tourist destinations recognized as one of the environmental elements for tourists' attraction (Chin, Lo, Songan, \& Nair, 2014) which it helps to strengthen the 
destination sense of place and civic pride. However, for several rural tourist destinations it still needs other supportive attraction in order to provide overall satisfaction to the visitors. Integrating others resources that belong to the destination could enhance the level of tourist satisfaction and experience. Thus, highlighting the different and core product that is locally produced would help in creating more tourism activity in a particular place (Samuel Folorunso Adeyinka-Ojo \& KhooLattimore, 2013).

The natural resources such as local food ingredients that incorporated in local cuisine potentially to be used to enhance rural destination development like Lenggong Valley. As a destination rich with natural resource products such as freshwater fish, houses a number of deer farm, fresh plants and vegetables which it can be tapped as potential future tourism product in Lenggong Valley. Siti Hajar Abd Aziz et al., (2014) suggest the uniqueness of local traditional dishes and the rich knowledge from local people regarding their using of many fresh plants and vegetables ought to be recognized as one of the cultural product in the Lenggong Valley. According to Razli Ahmad (personal communication, October 30, 2016) one of village headman, traditional local food products in Lenggong Valley such as Kebebe (a raw fruits paste-consist of 13 types of local fruits), daging masak patani (beef cooked with patani herbs and spices), kerabu umbut (salad made from young palm tree shoot), nasi buluh (rice in bamboo), masak lemak ikan pekasam (fermented fish in coconut milk gravy) and many more which have made mostly using natural resources by the local people since ancient time. The creativity of local communities in diversifying the natural resources are evident in the assortment of interesting recipes, some which are still passed down from generation to generation Thus, incorporating local food activity such as cooking demonstration in the Lenggong Valley tourist event calendar might help to attract more international tourists. This strategy also can be promoted through media such as food magazine, television, newspaper and internet which can enhance the destination image as well as providing some information about other attractions in Lenggong Valley.

In order to promote Lenggong Valley as a future food tourism destination, a concrete strategic framework needs to be developed by identifying the right local culinary products and combine with tourism resources possess by the destination. This is because with the appropriate marketing strategy focuses on local food it will help tourist to experience the beauty of others culinary culture and promote the cultural image of the tourism destination. The increasing of tourist satisfaction will lead to tourist behavioural intention to a particular destination. However, this effort and strategy would not be success without full cooperation between local community, tourism organization and other relevant authorities in tourist destination

\section{CONCLUSION}

Linkages between local food and tourism in rural area are seen as ways of promoting local entrepreneurs to be more economically and socially sustainable through increase tourists spending, diversify tourist experience and extension tourist seasons (Chiffoleau, 2009). Nevertheless, the involvement of the local communities in this industry is really important. The job opportunities in tourism related-business must be given priority to the local communities. According to Todaro \& Smith (1995), if the industry is unable to create job opportunities to the local communities, the traditional economic activities will remain the same and cause them to remain in poverty. There are 
many job can be created in rural tourist destination such as food business entrepreneur, tour guide, accommodation provider, transportation provider and many more. In addition, producing and growing more food locally could significantly retain the money by providing new economic opportunities to the local entrepreneurs, reducing 'food miles' and promotes healthier nutrition for the consumer (Green \& Dougherty, 2008). A case study in the island of Vororvo in Fiji Island examined tourists' perception on the local food menu (Pratt, 2013). Finding from this study reported that majority of the tourists were satisfied with the menu served and the tourists commented that the ingredients used are fresh and much healthier.

In conclusion, from the past studies, it shows the advantages of utilizing local food product as important element in contributing to destination sustainability and competitiveness. Local food product is used to reflect of the destination culture and identity. Seemingly, local food is appropriate product to offer as an attraction in a destination and has potentially to be incorporated in the tourism destination marketing.

This local food products possess by rural destination can be promoted through public material or website. Since competition is a global phenomenon, it essential requirement for the tourist destinations to start recognized the capabilities and strength of their local food potentials in term of history, identity and characteristic in order to portray an image of the destination's culture. Thus, emerging tourist destination such as Lenggong Valley might be utilized this strategy in order to enhance destination competitiveness and sustainability.

\section{Corresponding Author}

Mohd Nazri Abdul Raji, Faculty of Educational Studies, University Putra Malaysia, 43400 UPM Serdang, Selangor Darul Ehsan, Malaysia. E-mail: mohdnazrihm775@gmail.com

\section{References}

Ab Karim, S., \& Chi, C. G.-Q. (2010). Culinary Tourism as a Destination Attraction: An Empirical Examination of Destinations' Food Image. Journal of Hospitality Marketing \& Management, 19(6), 531-555. https://doi.org/10.1080/19368623.2010.493064

Adeyinka-Ojo, S. F., \& Khoo-Lattimore, and C. (2016). The role of regional foods and food events in rural destination development The case of Bario, Sarawak. In C. M. Hall \& and S. Gössling (Eds.), Food Tourism and Regional Development: Networks, products and trajectories. Abingdon, Oxon: Routledge.

Andersson, T. D., Mossberg, L., \& Therkelsen, A. (2017). Food and tourism synergies: perspectives on consumption, production and destination development. Scandinavian Journal of Hospitality and Tourism, 17(1), 1-8. https://doi.org/10.1080/15022250.2016.1275290

Ballantyne, R., Packer, J., \& Hughes, K. (2009). Tourists' support for conservation messages and sustainable management practices in wildlife tourism experiences. Tourism Management, 30(5), 658-664. https://doi.org/10.1016/j.tourman.2008.11.003

Bessière, J. (1998). Local Development and Heritage: Traditional Food and Cuisine as Tourist Attractions in Rural Areas. Sociologia Ruralis Volume, 38(1). 
INTERNATIONAL JOURNAL OF ACADEMIC RESEARCH IN BUSINESS AND SOCIAL SCIENCES Vol. 8, No. 10, Oct. 2018, E-ISSN: 2222-6990 @ 2018 HRMARS

Bessière, J. (2013). "heritagisation", a challenge for tourism promotion and regional development: An example of food heritage. Journal of Heritage Tourism, 8(4), 275-291. https://doi.org/10.1080/1743873X.2013.770861

Boniface, P. (2003). Tasting tourism: travelling for food and drink. Ashgate Publishing Limited: Aldersho. https://doi.org/10.1016/j.tourman.2004.02.009

Brown, F., \& Hall, D. (2000). Tourism in peripheral areas. Victoria Road, Clevedon: Channel View Publications.

Cawley, M., \& Gillmor, D. A. (2008). Integrated rural tourism:. Concepts and Practice. Annals of Tourism Research, 35(2), 316-337. https://doi.org/10.1016/j.annals.2007.07.011

Cheong, S. M., \& Miller, M. L. (2000). Power and tourism: A Foucauldian observation. Annals of Tourism Research, 27(2), 371-390. https://doi.org/10.1016/S0160-7383(99)00065-1

Chiffoleau, Y. (2009). From politics to Co-Operation: The dynamics of Embeddedness in Alternative Food Supply Chains. Sociologia Ruralis, 49(3), 218-235. https://doi.org/10.1111/j.14679523.2009.00491.x

Chin, C.-H., Lo, M.-C., Songan, P., \& Nair, V. (2014). Rural Tourism Destination Competitiveness: A Study on Annah Rais Longhouse Homestay, Sarawak. Procedia - Social and Behavioral Sciences, 144, 35-44. https://doi.org/10.1016/j.sbspro.2014.07.271

Choe, J. Y. (Jacey), \& Kim, S. (Sam). (2018). Effects of tourists' local food consumption value on attitude, food destination image, and behavioral intention. International Journal of Hospitality Management, 71(November 2017), 1-10. https://doi.org/10.1016/j.ijhm.2017.11.007

Deneault, M. (2002). Acquiring a Taste for Cuisine Tourism : A Product Development Strategy.

du Rand, G.E., \& Heath, E. (2006). Towards a Framework for Food Tourism as an Element of Destination Marketing. Current Issues in Tourism, 9(3), 206-234. https://doi.org/10.2164/cit/226.0

du Rand, G., Heath, E., \& Alberts, N. (2003). The Role of Local and Regional Food in Destination Marketing : A South African Situation Analysis. Journal of Travel and Tourism Marketing, 14(3/4), 97-112. https://doi.org/10.4324/9781315043395

Enteleca Research and Consultancy Ltd. (2000). Tourists Attitudes Towards Regional and Local Foods. The Ministry of Agriculture Fisheries and Food and the Countryside Agency.

Everett, S., \& Slocum, S. L. (2013). Food and Tourism : An Effective Partnership ? A UK-Based Review. Journal of Sustainable Tourism, 21(6), 789-809. https://doi.org/10.1080/09669582.2012.741601

Fields, K. (2002). Demand for the gastronomy tourism product: motivational factors. In A.-M. Hjalager \& G. Richards (Eds.), Tourism and Gastronomy. London: Routledge.

Goldsmith, R. E., \& Tsiotsou, R. H. (2012). Introduction to Experiential Marketing. In R. E. Goldsmith \& R. H. Tsiotsou (Eds.), Strategic Marketing in Tourism Service (pp.xxxi-xl). Emerald Group Publishing Limited.

Green, G. P., \& Dougherty, M. L. (2008). Localizing Linkages for Food and Tourism: Culinary Tourism as a Community Development Strategy. Community Development, 39(3), 148-158. https://doi.org/10.1080/15575330809489674 
INTERNATIONAL JOURNAL OF ACADEMIC RESEARCH IN BUSINESS AND SOCIAL SCIENCES

Vol. 8, No. 10, Oct. 2018, E-ISSN: 2222-6990 @ 2018 HRMARS

Hashimoto, A., \& Telfer, D. J. (2006). Selling Canadian culinary tourism: Branding the global and the regional product. Tourism Geographies, 8(1), 31-55. https://doi.org/10.1080/14616680500392465

Hassan, F., Zakaria, Z., Hamid, N. A., Rindam, M., \& Hamamah, F. (2013). Peningkatan daya saing Lembah Lenggong berasaskan pelancongan sumber setempat. GEOGRAFIA Online Malaysian Journal of Society and Space, 9(2), 35-49.

Haven-tang, C., \& Jones, E. (2005). Using Local Food and Drink to Differentiate Tourism Destinations Through a Sense of Place. Journal of Culinary Science, 4:4, 69-86. https://doi.org/10.1300/J385v04n04

Hjalager, A., \& Corigliano, M. A. (2000). Food for Tourists : Determinants of an Image. International Journal of Tourism Research, 281-293.

Hjalager, A., \& Johansen, P. H. (2013). Food Tourism in Protected Areas -Sustainability for Producers , the Environment and Tourism ? Journal of Sustainable Tourism, 21(3), 417-433. https://doi.org/10.1080/09669582.2012.708041

Jaafar, M., Kayat, K., Tangit, T. M., \& Yacob, M. F. (2013). Nature-Based Rural Tourism and its Economic Benefits: A Case Study of Kinabalu National Park. Worldwide Hospitality and Tourism Themes, 5(4), 342-352. https://doi.org/10.1108/WHATT-03-2013-0016

Jalis, M. H. (2016). An Analysis of the Integration of Local Cuisine in International Destination Marketing Strategies for Malaysia. Phd Thesis, Southern Cross University, Lismore, NSW.

Jalis, M. H., Che, D., \& Markwell, K. (2014). Utilising Local Cuisine to Market Malaysia as a Tourist Destination. Procedia - Social and Behavioral Sciences, 144, 102-110. https://doi.org/10.1016/j.sbspro.2014.07.278

Jenkins, J., Dredge, D., \& Taplin, J. (2011). Destination Planning and Policy: Process and Practice. In Y. Wang \& A. Pizam (Eds.), Destination marketing and management : theories and application (pp. 21-38). Cambridge: CAB International.

Kim, S., \& Iwashita, C. (2016). Cooking identity and food tourism: The case of Japanese udon noodles. Tourism Recreation Research, 89-100. https://doi.org/10.1080/02508281.2016.1111976

Kim, Y. G., Eves, A., \& Scarles, C. (2009). Building a model of local food consumption on trips and holidays: A grounded theory approach. International Journal of Hospitality Management, 28(3), 423-431. https://doi.org/10.1016/j.ijhm.2008.11.005

Kivela, J., \& Crotts, J. C. (2006). Tourism and Gastronomy: Gastronomy's Influence on How Tourists Experience a Destination. Journal of Hospitality and Tourism Research, 30(3), 354-377. https://doi.org/10.1177/1096348006286797

Lin, L. Z., \& Yeh, H. R. (2013). Analysis of tour values to develop enablers using an interpretive hierarchy-based model in Taiwan. Tourism Management, 34, 133-144. https://doi.org/10.1016/j.tourman.2012.04.004

Long, L. M. (1998). Culinary Tourism: A Folkloristic Perspective on Eating and Otherness. Southern $\begin{array}{llll}\text { Folklore (Vol. 55). } & \text { Retrieved }\end{array}$ http://mysite.du.edu/ lavita/anth_3070_13s/_docs/long_culinary_tourism.rev.pdf 
INTERNATIONAL JOURNAL OF ACADEMIC RESEARCH IN BUSINESS AND SOCIAL SCIENCES

Vol. 8, No. 10, Oct. 2018, E-ISSN: 2222-6990 @ 2018 HRMARS

Long, L. M. (2004). Culinary Tourism. In P. B. Thompson \& D. M. Kaplan (Eds.), Encyclopedia of Food and Agricultural Ethics (pp. 1-8). Dordrecht: Springer Netherlands. https://doi.org/10.1007/978-94-007-6167-4_416-1

López-Guzmán, T., \& Sánchez-Cañizares, S. (2012). Gastronomy, Tourism and Destination Differentiation: A Case Study in Spain. Review of Economics \& Finance, 63-72.

Lunchaprasith, T. (2017). Gastronomic experience as a community development driver: the study of Amphawa Floating Market as community-based culinary tourism destination. Asian Journal of Tourism Research, 2(2), 84-116.

Nummedal, M., \& Hall, C. M. (2006). Local Food in Tourism : An Investigation of the New Zealand South Island's Bed and Breakfast Sector's Use and Perception of Local Food. Tourism Review International, 9, 365-378.

Okumus, B., Okumus, F., \& McKercher, B. (2007). Incorporating Local and International Cuisines in the Marketing of Tourism Destinations: The Cases of Hong Kong and Turkey. Tourism Management, 28(1), 253-261. https://doi.org/10.1016/j.tourman.2005.12.020

Pearson, D., \& Pearson, T. (2016). Branding Food Culture: UNESCO Creative Cities of Gastronomy. Journal of Food Products Marketing, 0(0), 1-14. https://doi.org/10.1080/10454446.2014.1000441

Pratt, S. (2013). Minimising Food Miles : Issues and Outcomes in an Ecotourism Venture in Fiji. Journal of Sustainable Tourism, 21(8), 1148-1165. https://doi.org/10.1080/09669582.2013.776060

Quan, S., \& Wang, N. (2004). Towards a structural model of the tourist experience: An illustration from food experiences in tourism. Tourism Management, 25(3), 297-305. https://doi.org/10.1016/S0261-5177(03)00130-4

Rahmani, Hajari, Karimian, \& Hajilo. (2013). Rural tourism development strategies using SWOT analysis : Case study. Life Science Journal.

Raji, M. N. A., Ab Karim, S., Ishak, F. A. C., \& Arshad, M. M. (2017). Past and present practices of the Malay food heritage and culture in Malaysia. Journal of Ethnic Foods. https://doi.org/10.1016/j.jef.2017.11.001

Ramli, Z. (2017). Heritage Tourism in Malaysia: Potential \& Challenges. The Social Sciences.

Rasoolimanesh, S. M., Dahalan, N., \& Jaafar, M. (2016). Tourists' perceived value and satisfaction in a community-based homestay in the Lenggong Valley World Heritage Site. Journal of Hospitality and Tourism Management, 26, 72-81. https://doi.org/10.1016/j.jhtm.2016.01.005

Razli Ahmad. (2016). Personel interview.

Renko, S., Renko, N., \& Polonijo, T. (2010). Understanding the Role of Food in Rural Tourism Development in a Recovering Economy. Journal of Food Products Marketing, 16(3), 309-324. https://doi.org/10.1080/10454446.2010.485096

Ritchie, J. R., \& Crouch, G. I. (2003). The Competitive Destination : A Sustainable Tourism Perspective. Wallingford: CABI Publishing.

Samuel Folorunso Adeyinka-Ojo, \& Khoo-Lattimore, C. (2013). Slow Food Events as a High Yield Strategy for Rural Tourism Destinations The Case of Bario, Sarawak. Worldwide Hospitality and Tourism Themes, 5(4), 342-352. https://doi.org/10.1108/WHATT-03-2013-0012 
INTERNATIONAL JOURNAL OF ACADEMIC RESEARCH IN BUSINESS AND SOCIAL SCIENCES

Vol. 8, No. 10, Oct. 2018, E-ISSN: 2222-6990 (C) 2018 HRMARS

Sims, R. (2009). Food, Place and Authenticity: Local Food and the Sustainable Tourism Experience. Journal of Sustainable Tourism, 17(3), 321-336. https://doi.org/10.1080/09669580802359293

Siti Hajar Abd Aziz, Zuraini Zakaria, \& Ziyad Rafiqi Mohammad. (2014). Authenticity of Ficus Hispida as a Local Traditional Product in the Lembah Lenggong World Heritage Site. 4Th International Conference on Tourism Research (4lctr), 12. https://doi.org/10.1051/shsconf/2014201098

Son, A., \& Xu, H. (2013). Religious food as a tourism attraction: The roles of buddhist temple food in western tourist experience. Journal of Heritage Tourism, 8(2-3), 248-258. https://doi.org/10.1080/1743873X.2013.767815

Steinmetz, R. (2010). Food, Tourism and Destination Differentiation: The Case of Rotorua, New Zealand. Auckland University of Technology.

Telfer, D. J., \& Wall, G. (1996). Linkages between Tourism and Food Production. Annals of Tourism Research, 23(3), 635-653. Retrieved from http://www.sciencedirect.com/science/article/pii/0160738395000879

Timothy, D. J. (1999). Participatory planning a view of tourism in Indonesia. Annals of Tourism Research, 26(2), 371-391. https://doi.org/10.1016/S0160-7383(98)00104-2

Todaro, M.P., \& Smith, S. C. (1995). Economic Development (11 edition). Addison -Wesley, Pearson.

Tosun, C. (2000). Limits to community participation in the tourism development process in developing countries. Tourism Management, 21(6), 613-633. https://doi.org/10.1016/S02615177(00)00009-1

Tourism Malaysia. (2016). Malaysia registered 25.7 million touirst in 2015. Kuala Lumpur, Malaysia, Malaysia.

Tourism Malaysia. (2017). Tourist arrival and receipts to Malaysia by year. Retrieved from http://www.tourism.gov.my/

UNTWO. (2016). Annual Report 2015. Annual Report. https://doi.org/10.18111/9789284418039

Wang, Y. (2011). Destination marketing and management. Destination Marketing and Management.

Wolf, E. (2006). Culinary Tourism : The Hidden Harvest. Duduque: Kendall/Huntt. 